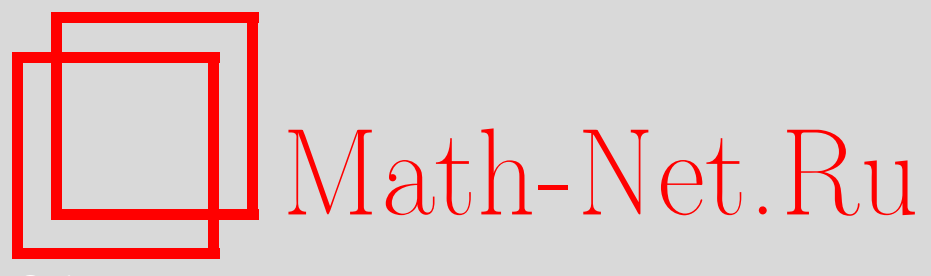

Л. Д. Беклемишев, В. М. Бухштабер, И. Г. Лысёнок, А. А. Мальцев, С. П. Новиков, А. А. Разборов, А. Л. Семёнов, Сергей Иванович Адян (к восьмидесятилетию со дня рождения), УМH, 2011, том 66, выпуск 1, 199 200

DOI: https://doi.org/10.4213/rm9414

Использование Общероссийского математического портала Math-Net.Ru подразумевает, что вы прочитали и согласны с пользовательским соглашением http://www.mathnet.ru/rus/agreement

Параметры загрузки:

IP : 54.80 .73 .141

26 апреля 2023 г., $17: 23: 03$

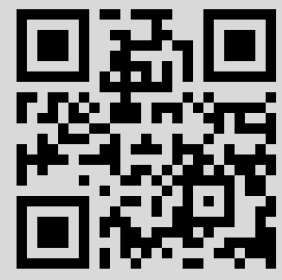




\section{Сергей Иванович Адян}

(к восьмидесятилетию со дня рождения)

1 января 2011 г. исполнилось 80 лет Сергею Ивановичу Адяну. Академик РАН С. И. Адян выдающийся ученый-математик, специалист в области алгебры, математической логики и теории алгоритмов, автор более 60 научных публикаций, в том числе 2 монографий. Он является одним из наиболее авторитетных и международно признанных лидеров в этих областях математики.

С.И. Адян получил фундаментальные результаты в области алгоритмических проблем распознавания групповых и полугрупповых свойств. Многие из полученных им результатов в настоящее время стали классическими. $\mathrm{K}$ ним можно отнести теорему об алгоритмической нераспознаваемости почти всех нетривиальных групповых свойств, что привело к решению ряда других алгоритмических проблем в математике. Его исследования структурных

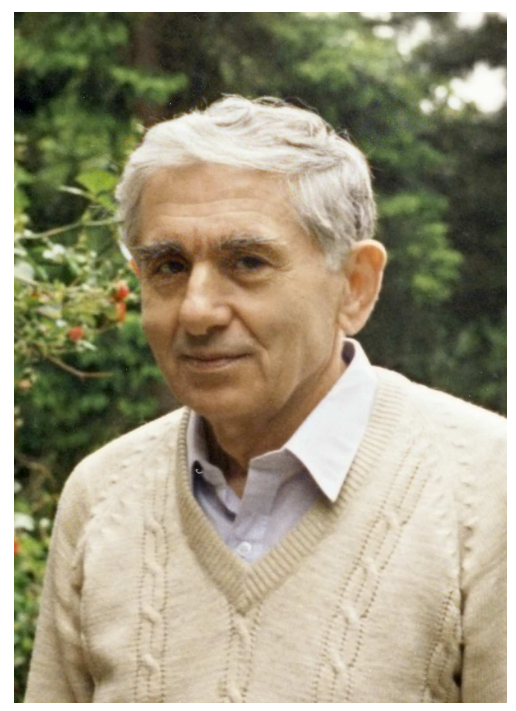
свойств групп и полугрупп, задаваемых определяющими соотношениями, позволили существенно продвинуться в решении простой по формулировке, но в действительности трудной проблемы распознавания равенства и делимости слов в полугруппах, заданных одним определяющим соотношением.

С.И. Адяном совместно с академиком П. С. Новиковым решена одна из труднейших проблем в алгебре, остававшаяся открытой с 1902 г., - проблема Бернсайда о периодических группах. Созданный при этом метод нашел применение для решения многих других известных проблем теории групп. В частности, С. И. Адяном впервые были построены некоммутативные аналоги аддитивной группы рациональных чисел, т. е. неабелевы группы с бесконечным пересечением любых двух нетривиальных подгрупп; найдены первые примеры бесконечных независимых систем групповых тождеств и тем самым решена известная проблема конечного базиса в теории групп; доказано, что нециклические свободные периодические группы нечетного периода $n \geqslant 665$ не только бесконечны, но и имеют экспоненциальный рост, т. е. в них число различных элементов данной длины растет как экспонента. С. И. Адян ввел новые операции умножения групп, известные как $n$-периодические произведения Адяна, и тем самым получил положительное решение проблемы А. И. Мальцева, поставленной еще в 1948 г. Эти операции обладают всеми свойствами классических операций свободного и прямого произведений групп, в том числе и свойством наследственности по подгруппам. В совместной работе С. И. Адяна и А. А. Разборова впервые была получена примитивно-рекурсивная верхняя оценка для порядков максимальных конечных групп данного простого периода и фиксированного ранга. 
Создание метода Новикова-Адяна и многочисленные результаты, полученные С.И. Адяном в процессе дальнейшего развития этого метода, представляют собой бесспорный прорыв российской математической науки в международном масштабе в области теории групп; лидирующее положение школы С.И. Адяна в этом направлении сохраняется и теперь.

С. И. Адян ведет многогранную научно-организационную работу. Он многие годы был членом Экспертного совета ВАК, Экспертного совета РФФИ по математике, Научной комиссии Отделения математики АН по школьному математическому образованию (в этой комиссии он работает и в настоящее время), председателем Специализированного совета ВАК по присуждению докторских степеней при Математическом институте им. В. А. Стеклова РАН.

С.И. Адян - член-корреспондент РАН с 1991 г. и действительный член РАН с 2000 г.; с 1973 г. он заведует отделом математической логики Математического института им. В.А. Стеклова РАН, с 1965 г. он профессор кафедры математической логики МГУ им. М. В. Ломоносова. С. И. Адян является создателем и руководителем одной из ведущих научных школ России по математике. Среди его учеников 3 члена-корреспондента РАН, 8 докторов и более 20 кандидатов наук.

С. И. Адян - лауреат Государственной премии РФ, Премии Московского математического общества, премии им. П. Л. Чебышёва АН СССР и международной премии им. Александра фон Гумбольдта (Германия), награжден медалью “За трудовую доблесть" (1975).

Л. Д. Беклемишев, В. М. Бухитабер, И. Г. Льсёнок, А. А. Мальцев, С. П. Новиков, А.А. Разборов, А. Л. Семёнов 